\title{
Structural-Phase State and Magnetotransport Properties of Thin Film Alloys Based on Permalloy and Copper
}

\author{
I.O. Shpetnyi1,*, K.V. Tyschenko, V.Ya. Pak ${ }^{1}$, B. V. Duzhyi ${ }^{2}$, Yu.O. Shkurdoda ${ }^{1}$ I.Yu. Protsenko \\ ${ }_{1}^{1}$ Sumy State University, 2, Rimsky-Korsakov St, 40007 Sumy, Ukraine \\ 2 National Aerospace University "Kharkiv Aviation Institute", 17, Chkalov St, 61070 Kharkiv, Ukraine
}

(Received 03 January 2021; revised manuscript received 15 February 2021; published online 25 February 2021)

\begin{abstract}
The paper presents the results of research influence of composition on structural-phase state and magnetoresistive properties of as-deposited and heat-treated at temperatures $T_{a} \leq 900 \mathrm{~K}$ samples film alloys based on Py and $\mathrm{Cu}$. Samples of thin film alloys with a thickness of $d=25 \mathrm{~nm}$ in the range of $19 \leq c_{\mathrm{Cu}} \leq 69$ (where $c_{\mathrm{Cu}}$ is the concentration of $\mathrm{Cu}$, at.\%) were obtained by the method of co-evaporation in vacuum from two independent evaporators. The structural-phase state of the samples of film alloys at $c_{\mathrm{Cu}}=19$ at.\%, 34 at.\% and 61 at.\% was investigated by the method of transmission electron microscopy. The structure of thin films in both as-deposited and annealed at $T_{a} \leq 900 \mathrm{~K}$ state consists of quasi granules with permalloy embedded in a nonmagnetic Cu matrix. The phase state of the samples at $c_{\mathrm{Cu}}=19$ at. $\%$ and $c_{\mathrm{Cu}}=34$ at.\% in the as-deposited state and after heat treatment at $T_{a}=600 \mathrm{~K}$ corresponded to fcc- $\mathrm{Ni}_{x} \mathrm{Fe}(x \approx 3)+$ fcc-Cu. After heat treatment at temperatures of $700 \leq T_{a} \leq 900 \mathrm{~K}$, the phase state of the samples at $c_{\mathrm{Cu}}=19$ at.\% and $c_{\mathrm{Cu}}=34$ at.\% corresponded to $\mathrm{Ni}_{3} \mathrm{Fe}+\mathrm{fcc}-\mathrm{Cu}$. For the film alloy sample at $c_{\mathrm{Cu}}=61$ at. $\%$ in the as-deposited state and after heat treatment at temperatures of $600 \leq T_{\mathrm{a}} \leq 900 \mathrm{~K}$, the phase state corresponded to fcc-Ni $\mathrm{Fe}_{x}(x \approx 3)+$ fcc-Cu. Studies of the magnetoresistive properties of film samples showed that the film samples in the entire range of compositions of $19 \leq c \mathrm{Cu} \leq 69$ at. $\%$ were characterized by isotropic magnetoresistance. The maximum value of the giant magnetoresistance was observed for the sample with $c_{\mathrm{Cu}}=34$ at.\% Both in the as-deposited state and after heat treatment at temperatures of $600 \leq T_{a} \leq 900 \mathrm{~K}$. Heat treatment of samples in the temperature range of $600 \leq T_{a} \leq 900 \mathrm{~K}$ had almost no effect on the value of GMR films at $19 \leq c_{\mathrm{Cu}} \leq 51$ at. $\%$.
\end{abstract}

Keywords: GMR effect, Granular state, Spin-dependent scattering, Permalloy, Superparamagnetism.

\section{INTRODUCTION}

Thin metal film materials are characterized by a number of phenomena, the study of which remains relevant today [1-6]. One such effect is the phenomenon of giant magnetoresistance (GMR) in multilayers and granular film alloys [7-10]. The discovery of the GMR phenomenon has aroused widespread interest in these nanostructures due to the possibility of their application in spintronics, sensor electronics, biotechnology, medicine, instrumentation and other fields [1, 2, 1115]. The effect of giant magnetoresistance is observed in granular magnetic films based on alloys of Co-Ag, $\mathrm{Fe}-\mathrm{Ag}$, Co-Cu, Permalloy-Ag, Permalloy-Cu, where magnetic granules with a size of units up to $100 \mathrm{~nm}$ are randomly placed in the volume of the non-magnetic matrix [13, 14, 16, 17]. The GMR effect is the result of spin-dependent scattering of conduction electrons at the interface between the nonmagnetic matrix and the magnetic granule or in the volume of the magnetic granule $[6,17]$. When making such samples in a magnetic field, their resistivity shows large changes. It is established that the physical properties of granular magnetic film materials are determined by their composition and, accordingly, the structural-phase state. The magnetic, magnetoresistive, magneto-optical and electrical properties can be controlled by the change of the film alloy composition, and accordingly affecting the size and concentration of magnetic granules in the nonmagnetic matrix [16]. Nowadays, the efforts of researchers are aimed at developing new film systems with specified physical properties and ensuring the stability of these properties under the action of various factors, including heat treatment.

To date, a large number of experimental results of the study of magnetic and magnetoresistive properties of multilayers and multilayer film systems based on permalloy (Py) and $\mathrm{Cu}$ [17-20]. $\mathrm{Py}$ and $\mathrm{Cu}$-based film systems are widely used due to certain unique features - low values of coercivity and saturation magnetization [1], thermal stability [19, 20], high sensitivity to the magnetic field [18]. Due to these properties, magnetic film systems have found practical application in biomedical technologies in the manufacture of biosensors [1], in automobile electronics [1], in spintronics in the manufacture of sensitive elements of magnetic field sensors [2], magnetic transducers, magnetoresistive random access memory [21]. In the works [19, 20] the authors studied the effect of annealing of multilayers based on permalloy and copper on their magnetic and magnetotransport properties, analyzed the mechanism of degradation of samples. However, studies of these effects for thin-film alloys in a wide range of compositions based on $\mathrm{Py}$ and $\mathrm{Cu}$, obtained by the method of simultaneous condensation of two independent evaporators in the literature are almost absent. The aim of this work was to study the influence of the composition of film samples based on $\mathrm{Py}$ and $\mathrm{Cu}$ with a thickness $d=25 \mathrm{~nm}$ on their structural-phase state and magnetoresistive properties under heat treatment.

\footnotetext{
*i.shpetnyi@aph.sumdu.edu.ua
} 


\section{EXPERIMENTAL DETAILS}

Samples of thin-film alloys based on permalloy and copper in a wide range of $19 \leq c_{\mathrm{Cu}} \leq 69$ (where $c_{\mathrm{Cu}}$ is the total copper concentration, at.\%) were obtained in a vacuum of $P \approx 10^{-4} \mathrm{~Pa}$ at room temperature. To obtain these film samples used the method of simultaneous evaporation of metals from two independent electron beam evaporators. The starting material for spraying Py was a massive portion of $\mathrm{Ni}_{80} \mathrm{Fe}_{20}$ permalloy. The deposition rate was $0.2 \mathrm{~nm} / \mathrm{s}$ for $\mathrm{Py}$ and $0.3 \mathrm{~nm} / \mathrm{s}$ for $\mathrm{Cu}$. The thickness of the film samples during the deposition process was controlled by the quartz resonator method [21]. Polished sieve substrates were chosen for deposition. All the obtained samples were obtained in one deposition cycle, therefore, they had the same thickness $d=25 \mathrm{~nm}$, but differed in the ratio of the concentration of the components. Annealing of samples at temperatures $T_{\mathrm{a}}=600,700$ and $900 \mathrm{~K}$ was carried out in a vacuum chamber at $P=10^{-4} \mathrm{~Pa}$ for a time $t=30 \mathrm{~min}$. The elemental composition of the obtained thin film samples was examined using scanning electron microscopy (SEM Jeol 7001TTLS) and energydispersion X-ray (EDX) spectroscopy (Oxford Instruments analyzer, XMax detector). An accelerating voltage of $10 \mathrm{kV}$ and an operating distance of $10 \mathrm{~mm}$ were used to obtain EDX spectra.

The structural-phase state of the samples was investigated by transmission electron microscopy (TEM) on the device TEM-125K (accelerating voltage $100 \mathrm{kV}$ ). Preparation of samples for research by the TEM method was carried out by deposition of permalloy and copper on a grid with a carbon film. Samples for research by TEM were obtained simultaneously with the samples for the study of magnetic transport properties, ie were identical.

The study of magnetoresistive properties was carried out at room temperature on an automatic measuring system in two geometric dimensions - transverse and longitudinal [23]. Measurements were performed by applying a magnetic field with an amplitude in the range $B_{\max } \pm 0.45 \mathrm{~T}$ using a 4 -point measurement scheme. In the transverse geometry of the measurement, the applied magnetic field was directed in the plane of the film, but perpendicular to the direction of the current $I$. In the longitudinal geometry of the measurement, the magnetic field was directed in the plane of the film and parallel to the direction of the current $I$ [22]. GMR values were calculated by the ratio $G M R=\Delta R / R\left(B_{\max }\right)=\left(R(B)-R\left(B_{\max }\right)\right) / R\left(B_{\max }\right) \quad$ [18], where $R(B)$ and $R\left(B_{\max }\right)$ are the resistance of the films in an arbitrary magnetic field $B$ and in the maximum field $B_{\max }$, respectively.

\section{RESULTS AN DISCUSSION}

\subsection{Structural State and Phase Composition}

The results of studies of the structural-phase state of film samples are very important for the interpretation of their magnetoresistive properties. The structural-phase state of samples of film alloys with copper concentrations of 19 at.\%, 34 at.\% and 61 at.\% was analyzed by TEM method in as-deposited state and after heat treatment. It should be noted that according to [24], in the massive and film states in permalloy alloys, depending on the ratio between the concentrations of $\mathrm{Ni}$ and $\mathrm{Fe}$, three crystalline phases can be formed. At $c \mathrm{Ni} \cong 63 \div 85$ at.\%, the phase composition of Py films corresponds to fcc- $\mathrm{Ni}_{3} \mathrm{Fe}$ (structural type $\mathrm{Cu}_{3} \mathrm{Au}$ ) with the lattice parameter $a=0.354 \div 0.359 \mathrm{~nm}$. At concentrations of $c \mathrm{Ni} \cong 50$ at.\% in the films, the fcc-Ni-Fe phase (structural type $\mathrm{CuAu}$ ) with the lattice parameter $a=0.359 \div 0.361 \mathrm{~nm}$ is stabilized. At $c \mathrm{Ni} \cong 25$, the bcc $\alpha$-Fe-Ni phase with the lattice parameter $a=0.286 \mathrm{~nm}$ is stabilized.

In Figs. 1 and 2 microstructure images and diffraction spectra are presented for a film sample with a total copper concentration $c_{\mathrm{Cu}}=19$ at.\% in as-deposited state and after heat treatment at 600 and $700 \mathrm{~K}$. On the inserts Fig. 1a, b the corresponding diffraction patterns for film samples are given. The diffraction pattern was transformed into a spectrum, by software created in the programming language Lab View. On Fig. 2 diffraction spectra for the images of diffraction pattern presented on Fig. 1. Vertical lines on Fig. 2 indicate the tabular data of the diffraction lines for massive samples of fcc-Cu, fcc-Ni-Fe and fcc-Nis Fe. The decoding of diffraction patterns was performed taking into account the positions of the peaks in the diffraction spectra for as-deposited and heat-treated samples.

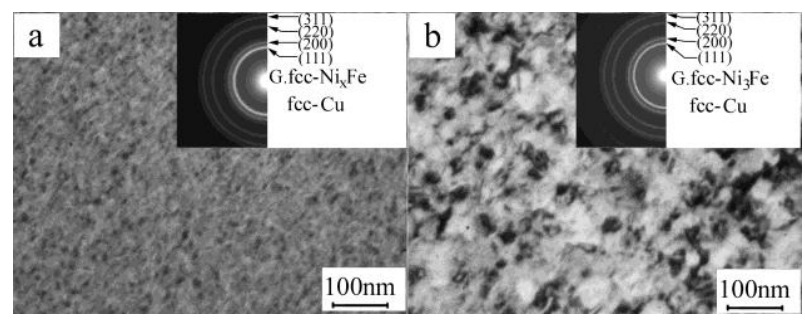

Fig. 1 - Microstructure of thin-film alloy based $\mathrm{Py}$ and $\mathrm{Cu}$ with a concentration of copper $c_{\mathrm{Cu}}=19$ at.\% in as-deposited state (a) and after heat treatment at $700 \mathrm{~K}$ (b). The inserts show the corresponding diffraction patterns

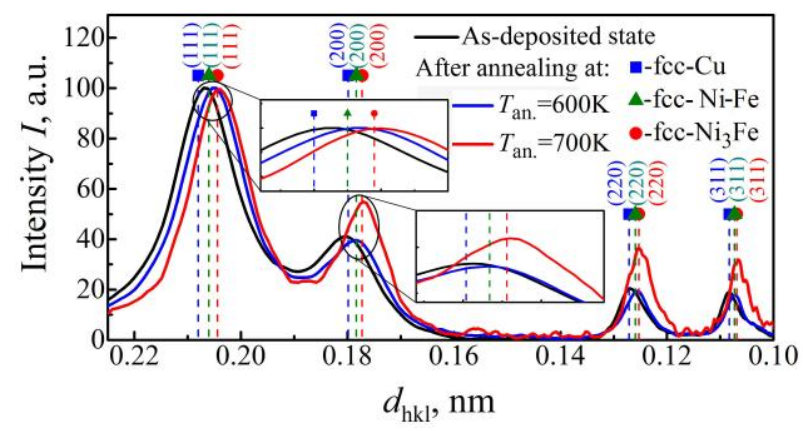

Fig. 2 - Diffraction spectra from samples of alloy thin films based on $\mathrm{Py}$ and $\mathrm{Cu}$ with a total concentration of $c_{\mathrm{Cu}}=19$ at.\% in as-deposited state and after heat treatment at different temperatures $T_{\mathrm{a}}$

Analysis of the research results showed that the phase state of this sample in the as-deposited state corresponds to fcc- $\mathrm{Ni}_{x} \mathrm{Fe}(x \approx 3)+$ fcc- $\mathrm{Cu}$. The size of the quasi granules (G) permalloy was $L=7 \div 18 \mathrm{~nm}$ (Fig. 1a). Lines of fcc-Cu and fcc- $\mathrm{Ni}_{x} \mathrm{Fe}$, cannot be separated on the diffraction pattern due to close interplanar distances. Deviations from the composition $\mathrm{Ni}_{3} \mathrm{Fe}$ to $\mathrm{Ni}_{x} \mathrm{Fe}(x \approx 3)$ may caused 
by the dissociation of $\mathrm{Ni}_{3} \mathrm{Fe}$ permalloy to $\mathrm{Ni}$ and $\mathrm{Fe}$ atoms during the process of electron beam evaporation. A phase can be formed from these atoms fcc-Ni-Fe. In addition, the diffusion of $\mathrm{Ni}$ and $\mathrm{Fe}$ atoms may result in the formation of dilute solid solutions fcc- $\mathrm{Cu}(\mathrm{Ni})$ and fcc- $\mathrm{Cu}(\mathrm{Fe})$. After heat treatment of the film sample with the total concentration of copper $c \mathrm{Cu}=19$ at.\% at $T_{\mathrm{a}}=700 \mathrm{~K}$ the phase state corresponded fcc- $\mathrm{Cu}+$ fcc$\mathrm{Ni}_{3} \mathrm{Fe}$. During heat treatment of samples due to thermal diffusion of $\mathrm{Ni}$ atoms and their attachment to the granules $\mathrm{Ni}_{x} \mathrm{Fe} \mathrm{Ni}_{3} \mathrm{Fe}$ stoichiometry is renewed as in the material of the original sample. The size of the quasi granules was $L=7 \div 23 \mathrm{~nm}$ (Fig. 1b).

Structural-phase state of the film sample with the total concentration of copper $c \mathrm{Cu}=34$ at.\% in the asdeposited state and after heat treatment (Fig. 3 and 4) similar to the state of the sample at $c_{\mathrm{Cu}}=19$ at.\%. Asdeposited films were characterized by a state in which quasi granules fcc- $\left(\mathrm{Ni}_{x} \mathrm{Fe}\right) \quad(x \approx 3)$ size $L=7 \div 15 \mathrm{~nm}$ (Fig. 3a) were in a nonmagnetic matrix with fcc-Cu. The results of decoding diffraction patterns are presented in Table 1 . Annealing at $T_{\mathrm{a}}=600 \mathrm{~K}$ did not cause changes in phase state (Fig. $3 \mathrm{~b}$ ). The size of the quasi granules was $L=8 \div 16 \mathrm{~nm}$. After heat treatment of the film samples at $T_{a} \geq 700 \mathrm{~K}$, the phase state corresponded fcc- $\mathrm{Ni}_{3} \mathrm{Fe}+\mathrm{fcc}-\mathrm{Cu}$. Annealing of the samples at $T_{a}=700 \mathrm{~K}$ and $T_{a}=900 \mathrm{~K}$ increased the size of the quasi granules with permalloy to $L=8 \div 21 \mathrm{~nm}$ (Fig. 3c) and $L=27 \div 43 \mathrm{~nm}$, respectively.

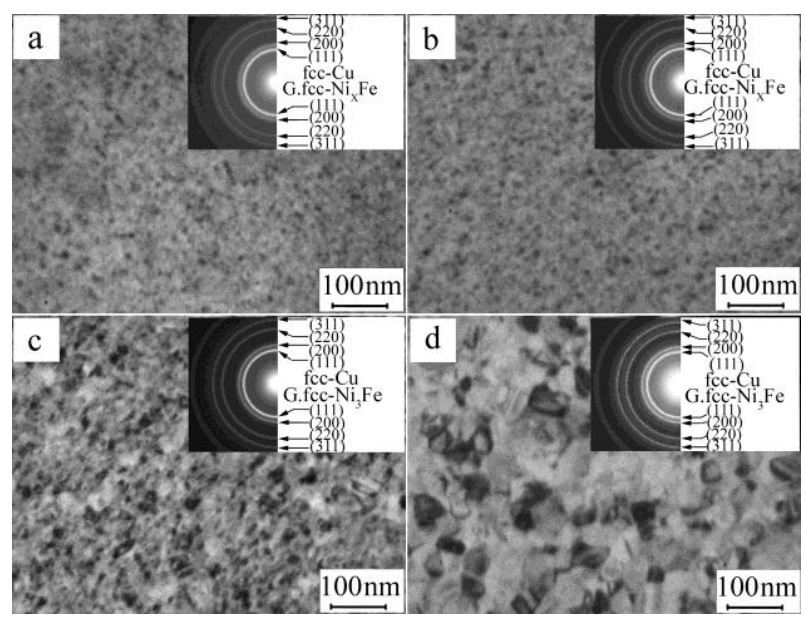

Fig. 3 - Microstructure of thin-film alloy based $\mathrm{Py}$ and $\mathrm{Cu}$ with a concentration of copper $c_{\mathrm{Cu}}=34$ at.\% in as-deposited state (a) and after heat treatment at 600 (b), 700 (c) and $900 \mathrm{~K}$ (d). The inserts show the corresponding diffraction patterns

Analysis of the phase composition of the film sample at $c_{\mathrm{Cu}}=61$ at.\% in as-deposited state and after heat treatment at temperatures of $600 \leq T_{a} \leq 900 \mathrm{~K}$ corresponded to fcc- $\mathrm{Ni}_{x} \mathrm{Fe}(x \approx 3)+$ fcc-Cu (Fig. 5). The results of decoding the diffraction spectra (Fig. 6) are given in Table 1. No renewal $\mathrm{Ni}_{x} \mathrm{Fe}$ to the stoichiometry of $\mathrm{Ni}_{3} \mathrm{Fe}$ occurred during heat treatment of the samples caused by to the thermal diffusion of $\mathrm{Ni}$ atoms, possibly because of the low total concentration of the magnetic component and, accordingly, the $\mathrm{Ni}$ atoms in the sample.

The structures of thin films in both as-deposited and annealed at $T \leq 900 \mathrm{~K}$ states consist of permalloy fcc- $\mathrm{Ni}_{x} \mathrm{Fe}$ quasi granules embedded in a $\mathrm{Cu}$ non- magnetic matrix. The size of the granules in asdeposited and heat-treated at 600,700 and $900 \mathrm{~K}$ states were $L=6 \div 10 \mathrm{~nm} \quad$ (Fig. 1a), $L=8 \div 12 \mathrm{~nm}$ (Fig. 1b), $L=8 \div 19 \mathrm{~nm}$ (Fig. 1c) and $L=8 \div 23 \mathrm{~nm}$ (Fig. 1d), respectively.

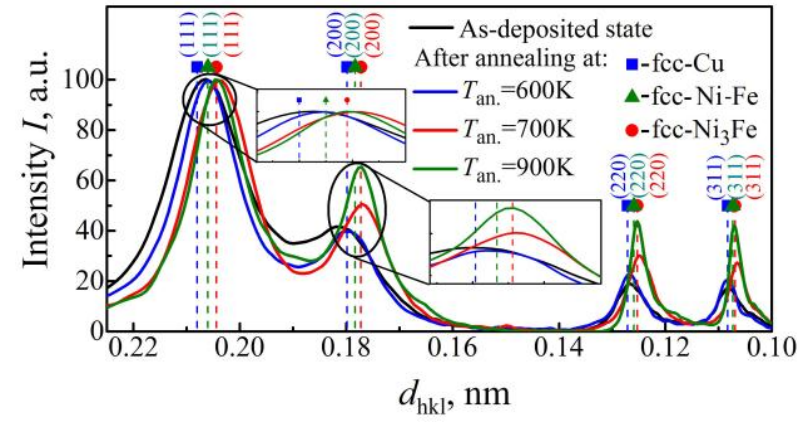

Fig. 4 - Diffraction spectra from samples of alloy thin films based on $\mathrm{Py}$ and $\mathrm{Cu}$ with a total concentration of $\mathrm{c} \mathrm{Cu}=34$ at.\% in as-deposited state and after heat treatment at different temperatures $T_{0}$

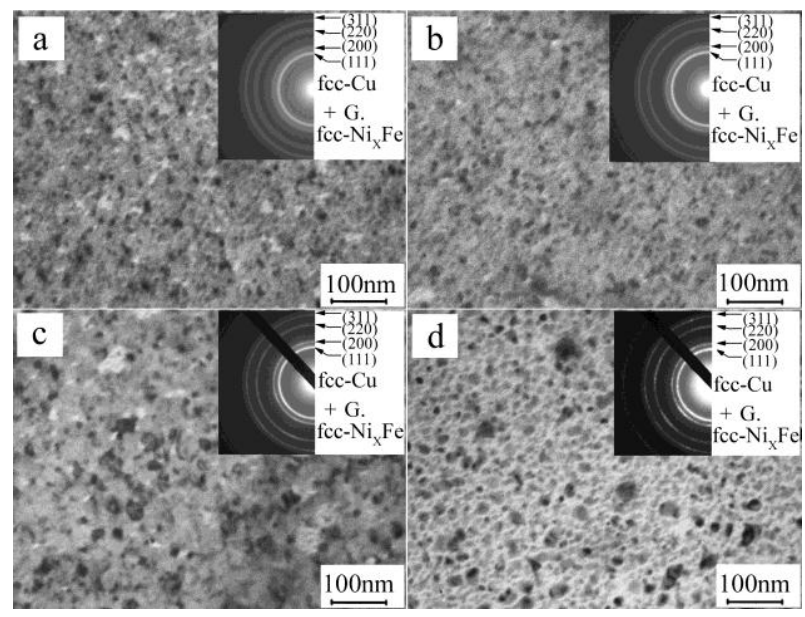

Fig. 5 - Microstructure of thin-film alloy based $\mathrm{Py}$ and $\mathrm{Cu}$ with a concentration of copper $c_{\mathrm{Cu}}=61$ at.\% in as-deposited state (a) and after heat treatment at 600 (b), 700 (c) and $900 \mathrm{~K}$ (d). The inserts show the corresponding diffraction patterns

\subsection{Magnetoresistive Properties}

The results of the study on the magnetoresistive properties in as-deposited state and after heat treatment alloys thin films based on $\mathrm{Py}$ and $\mathrm{Cu}$ are shown below. On Fig. 7 the dependence of the GMR value on the total concentration of copper in the film alloy is given. Magnetoresistance studies were performed in the transverse (Fig. 7a) and longitudinal (Fig. 7b) measurement geometries at room temperature in an external magnetic field $B \leq \pm 0.45 \mathrm{~T}$. At low total concentrations of copper in the alloy (for example, when $c_{\mathrm{Cu}}=19$ at. $\%$ and $c \mathrm{Cu}=26$ at.\%) quasi granules with permalloy, can touch each other, form a normal ohmic conduction channel. Therefore, in this case, the spindependent scattering of conduction electrons is inefficient, and the amplitude of the GMR is correspondingly small $\left(\mathrm{GMR}_{\max } \approx 0.1 \%\right.$ in the as-deposited state for the sample with $c_{\mathrm{Cu}}=19$ at.\%).

The increasing total copper concentration to $c_{\mathrm{Cu}}=34$ at. $\%$ rises the amplitude of GMRs up to $0.21 \%$, 
the maximum value for as-deposited samples. In Fig. 8. field dependences for a sample of a film sample on the basis of permalloy and copper at the general concentration of copper are resulted $c_{\mathrm{Cu}}=34$ at.\%. The lack of saturation on the field dependences of the magnetoresistance (Fig. 8) indicates that the structural state of

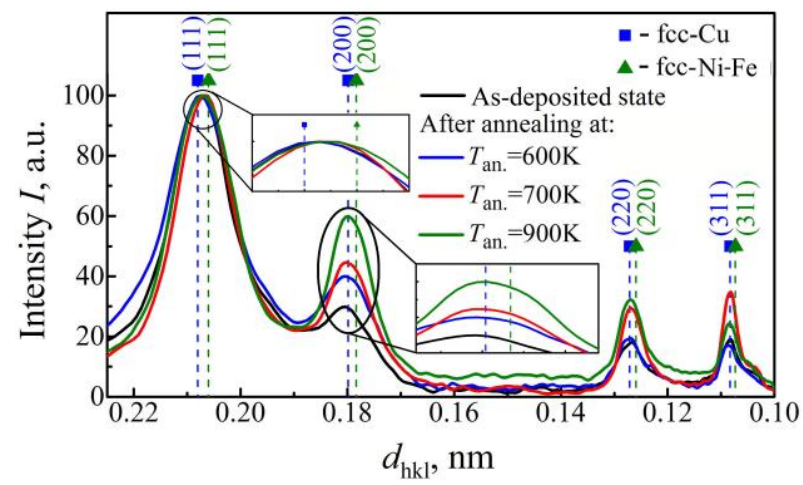

Fig. 6- Diffraction spectra from samples of alloy thin films based on $\mathrm{Py}$ and $\mathrm{Cu}$ with a total concentration of $c_{\mathrm{Cu}}=61$ at.\% in as-deposited state and after heat treatment at different temperatures $T_{a}$

this sample corresponds to the superparamagnetic granules placed in a nonmagnetic matrix. Heat treatment of a sample with a total concentration of copper
$c_{\mathrm{Cu}}=34$ at. $\%$ at temperature $T_{a}=600 \mathrm{~K}$ led to an increase in the value of GMRs by $38 \%$ and $14 \%$ of the value obtained for as-deposited samples in the transverse and longitudinal geometry of the measurement, respectively. However, further heat treatment of the sample in the temperature range of $600<T_{a} \leq 900 \mathrm{~K}$ almost did not change the value of its magnetoresistance (Figs. 7 and 8 ).

Further increase total copper concentration to 51: 69 at.\% caused reducing the amplitude of the magnetoresistance to $0.02-0.05 \%$ in an external magnetic field of $0.45 \mathrm{~T}$. The field dependences of the magnetoresistance of such samples are linear, do not show hysteresis and are not saturated in fields up to $0.45 \mathrm{~T}$. This behavior of the magnetoresistance indicates that the structural state of these films corresponds to the ensemble of weakly interacting superparamagnetic granules. This is confirmed by the results of the study of the structural state, performed by the TEM method.

It should be noted that for film samples with a total concentration of copper $19 \leq c \mathrm{Cu} \leq 51$ at.\% the thermal stability of the magnetoresistance was observed. This feature of the magnetic transport properties of film systems based on $\mathrm{Py}$ and $\mathrm{Cu}$ can be used in the manufacture of instrument structures. Thermal stability of magnetoresistive properties was also observed by the authors in multilayers based on permalloy and copper [20].

Table 1 - Deciphering the diffraction patterns from $\mathrm{Py}$ and $\mathrm{Cu}$ alloy films with concentration of $\mathrm{Cu} 34$ at.\% and 61 at.\% in asdeposited state and after heat treatment

\begin{tabular}{|c|c|c|c|c|c|c|c|c|c|c|c|c|}
\hline No & $\begin{array}{l}, \\
\%\end{array}$ & $\begin{array}{c}d_{\mathrm{hkl}}, \\
\mathrm{nm}\end{array}$ & $h k l$ & Phase state & No & $\begin{array}{l}I, \\
\%\end{array}$ & $\begin{array}{c}d_{\mathrm{hkl}}, \\
\mathrm{nm}\end{array}$ & $h k l$ & Phase state & \multirow{2}{*}{\multicolumn{3}{|c|}{ Table values $d_{\mathrm{hkl}}, \mathrm{nm}$}} \\
\hline \multicolumn{10}{|c|}{$c_{\mathrm{Cu}}=34$ at. $\%$} & & & \\
\hline \multicolumn{5}{|c|}{ As-deposited sample } & \multicolumn{5}{|c|}{ After annealing at $T_{a}=900 \mathrm{~K}$} & $\mathrm{fcc}-\mathrm{Cu}$ & $\begin{array}{c}\text { fcc- } \\
\mathrm{Ni}-\mathrm{Fe}\end{array}$ & $\begin{array}{c}\text { fcc- } \\
\mathrm{Ni}_{3} \mathrm{Fe}\end{array}$ \\
\hline 1 & 100 & 0.2066 & 111 & $\begin{array}{l}\text { fcc-Cu } \\
\text { G. fcc- } \mathrm{Ni}_{x} \mathrm{Fe}\end{array}$ & 1 & 100 & 0.2040 & 111 & $\begin{array}{l}\text { fcc-Cu } \\
\text { G. fcc- } \mathrm{Ni}_{3} \mathrm{Fe}\end{array}$ & 0.2080 & 0.2060 & 0.2044 \\
\hline 2 & 40 & 0.1808 & 200 & $\begin{array}{l}\text { fcc-Cu } \\
\text { G. fcc-Nix } \mathrm{Fe}\end{array}$ & 2 & 65 & 0.1774 & 200 & $\begin{array}{l}\text { fcc-Cu } \\
\text { G. fcc-Nis } \mathrm{Fe}\end{array}$ & 0.1798 & 0.1783 & 0.1772 \\
\hline 3 & 20 & 0.1268 & 220 & $\begin{array}{l}\text { fcc-Cu } \\
\text { G. fcc-Ni } \mathrm{Ni}_{x} \mathrm{Fe}\end{array}$ & 3 & 40 & 0.1251 & 220 & $\begin{array}{l}\text { fcc-Cu } \\
\text { G. fcc- } \mathrm{Ni}_{3} \mathrm{Fe}\end{array}$ & 0.1271 & 0.1259 & 0.1253 \\
\hline 4 & 20 & 0.1084 & 311 & $\begin{array}{l}\text { fcc-Cu } \\
\text { G. fcc-Nix } \mathrm{Fe}\end{array}$ & 4 & 40 & 0.1070 & 311 & $\begin{array}{l}\text { fcc-Cu } \\
\text { G. fcc- } \mathrm{Ni}_{3} \mathrm{Fe}\end{array}$ & 0.1083 & 0.1073 & 0.1069 \\
\hline \multicolumn{5}{|c|}{$a=0.359 \pm 0.001 \mathrm{~nm}$} & \multicolumn{5}{|c|}{$a=0.355 \pm 0.001 \mathrm{~nm}$} & & & \\
\hline \multicolumn{10}{|c|}{$c_{\mathrm{Cu}}=61$ at. $\%$} & & & \\
\hline \multicolumn{5}{|c|}{ As-deposited sample } & \multicolumn{5}{|c|}{ After annealing at $T_{a}=700 \mathrm{~K}$} & $\mathrm{fcc}-\mathrm{Cu}$ & $\begin{array}{c}\text { fcc- } \\
\text { Ni-Fe }\end{array}$ & $\begin{array}{c}\text { fcc- } \\
\mathrm{Ni}_{3} \mathrm{Fe}\end{array}$ \\
\hline 1 & 100 & 0.2076 & 111 & $\begin{array}{l}\text { fcc-Cu } \\
\text { G. fcc-Nix } \mathrm{Fe}\end{array}$ & 1 & 100 & 0.2072 & 111 & $\begin{array}{l}\text { fcc-Cu } \\
\text { G. fcc-Nix } \mathrm{Fe}\end{array}$ & 0.2080 & 0.2060 & 0.2044 \\
\hline 2 & 30 & 0.1808 & 200 & $\begin{array}{l}\text { fcc-Cu } \\
\text { G. fcc-Ni } \mathrm{Ni}_{x} \mathrm{Fe}\end{array}$ & 2 & 45 & 0.1798 & 200 & $\begin{array}{l}\text { fcc-Cu } \\
\text { G. fcc-Ni } \mathrm{Ni}_{x} \mathrm{Fe}\end{array}$ & 0.1798 & 0.1783 & 0.1772 \\
\hline 3 & 20 & 0.1269 & 220 & $\begin{array}{l}\text { fcc-Cu } \\
\text { G. fcc-Ni } \mathrm{Ni}_{\times} \mathrm{Fe}\end{array}$ & 3 & 30 & 0.1269 & 220 & $\begin{array}{l}\text { fcc-Cu } \\
\text { G. fcc-Ni } \mathrm{Ni}_{x} \mathrm{Fe}\end{array}$ & 0.1271 & 0.1259 & 0.1253 \\
\hline 4 & 20 & 0.1089 & 311 & $\begin{array}{l}\text { fcc- } \mathrm{Cu} \\
\text { G. fcc-Ni } \mathrm{Ni}_{\mathrm{x}} \mathrm{Fe}\end{array}$ & 4 & 35 & 0.1083 & 311 & $\begin{array}{l}\text { fcc-Cu } \\
\text { G. fcc-Ni } \mathrm{Ni}_{x} \mathrm{Fe}\end{array}$ & 0.1083 & 0.1073 & 0.1069 \\
\hline \multicolumn{5}{|c|}{$a=0.360 \pm 0.001 \mathrm{~nm}$} & \multicolumn{5}{|c|}{$a=0.359 \pm 0.001 \mathrm{~nm}$} & & & \\
\hline
\end{tabular}

It should be noted that studies of the magnetoresistive properties of the samples showed that film alloys based on $\mathrm{Py}$ and $\mathrm{Cu}$ in the entire studied range of compositions $19 \leq c_{\mathrm{Cu}} \leq 69$ at.\% In the as-deposited state and after heat treatment to $T_{a} \leq 900 \mathrm{~K}$ were characterized by an isotropic magnetoresistance. It means, the behavior of the magnetoresistance curves obtained in the transverse and longitudinal geometries of the measurement had a similar character.

\section{CONCLUSIONS}

1. The correlation between the composition, structural-phase state and magnetoresistive properties of samples of film alloys based on $\mathrm{Py}$ and $\mathrm{Cu}$ with a thickness of $d=25 \mathrm{~nm}$ in the as-deposited state and after heat treatment at $T_{a} \leq 900 \mathrm{~K}$ was experimentally confirmed.

2. The structural-phase state of samples of film al- 
loys at $c_{\mathrm{Cu}}=19$ at.\%, 34 at.\% and 61 at.\% was investigated by TEM method. The structure of film systems in the as-deposited state and after heat treatment at $T \leq$

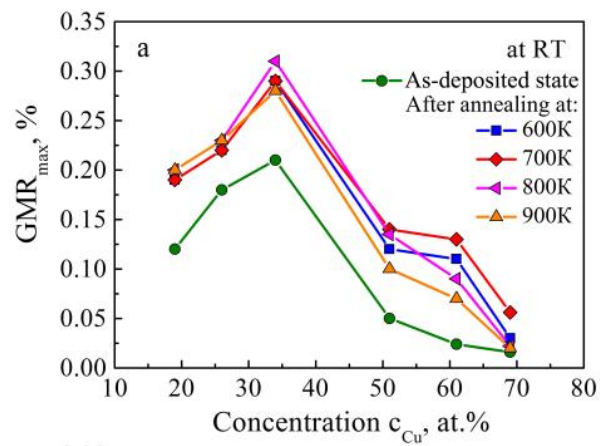

$900 \mathrm{~K}$ consists of quasi-permalloy granules embedded in a nonmagnetic $\mathrm{Cu}$ matrix. Phase state of samples at $c_{\mathrm{Cu}}=19$ at. $\%$ and $c_{\mathrm{Cu}}=34$ at.\% in as-deposited

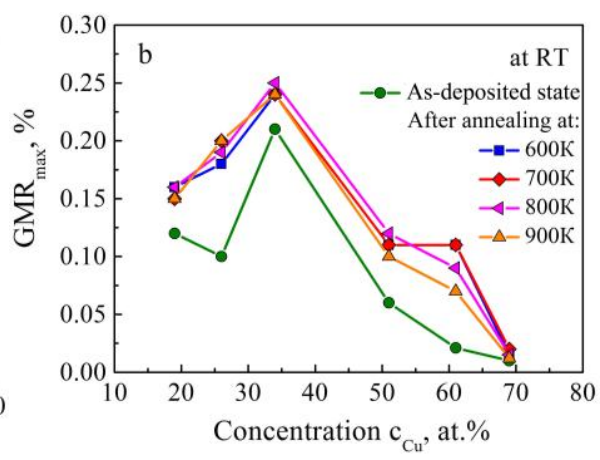

Fig. 7 - The magnetoresistance in transverse (a) and longitudinal (b) geometries of nanogranular alloy thin films based on Py and $\mathrm{Cu}$ as a function of $\mathrm{Cu}$ atomic concentration, in as-deposited state and after annealing at different temperatures $T_{\mathrm{a}}$. The measurements were performed at room temperature in magnetic field $B_{\max }=0.45 \mathrm{~T}$
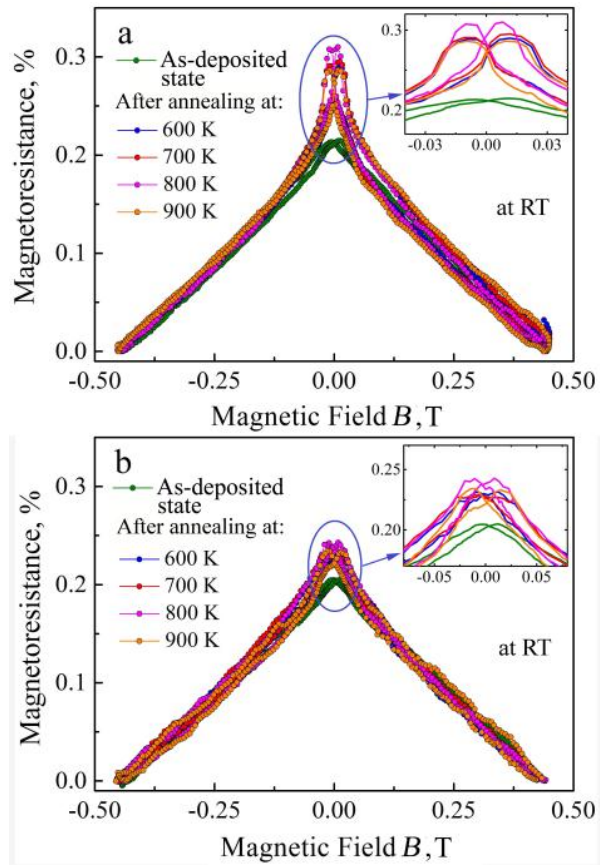

Fig. 8 - The magnetoresistive curves measured in transverse (a) and longitudinal (b) geometries at the room temperature for the as-deposited and annealed at different temperatures nanogranular alloy thin films based on $\mathrm{Py}$ and $\mathrm{Cu}$ with a total concentration of $c_{\mathrm{Cu}}=34$ at.\%

\section{REFERENCES}

1. L. Jogschies, D. Klaas, R. Kruppe, J. Rittinger, P. Taptimthong, A. Wienecke, L. Rissing, M.C. Wurz, Sensors 15, 28665 (2015).

2. I. Ennen, D. Kappe, T. Rempel, C. Glenske, A. Hütten, Sensors 16, 904 (2016).

3. I.Yu. Protsenko, L.V. Odnodvorets, V. Bondariev, K. Tyschenko, I.V. Cheshko, N.I. Shumakova, Vacuum 165, 113 (2019).

4. S. Vorobiov, D. Tomasova, V. Girman, H. You, E. Čižmár, M. Orendáć, V. Komanicky, J. Magn. Magn. Mater. 474, 63 (2019).

5. A.M. Chornous, Yu.O. Shkurdoda, V.B. Loboda, state and after heat treatment at $T_{a}=600 \mathrm{~K}$ corresponded to fcc- $\mathrm{Ni}_{x} \mathrm{Fe}(x \approx 3)+$ fcc- $\mathrm{Cu}$. After heat treatment at temperatures $700 \leq T_{a} \leq 900 \mathrm{~K}$ phase state of the samples with concentrations of $c_{\mathrm{Cu}}=19$ at.\% and $c \mathrm{Cu}=34$ at. $\%$ corresponded to $\mathrm{Ni}_{3} \mathrm{Fe}+\mathrm{fcc}-\mathrm{Cu}$. For a sample of a film alloy at $c_{\mathrm{Cu}}=61$ at.\% In the asdeposited state and after heat treatment at temperatures of $600 \leq T_{a} \leq 900 \mathrm{~K}$ phase state corresponded to fcc-Ni $\mathrm{Ni}_{x} \mathrm{Fe}(x \approx 3)+$ fcc-Cu.

3 . Studies of the magnetoresistive properties of the measured samples showed that film systems based on $\mathrm{Py}$ and $\mathrm{Cu}$ in the entire range of compositions $19 \leq c \mathrm{cu} \leq 69$ at.\% are characterized by isotropic magnetoresistance. The maximum value of the giant magnetoresistance was observed for a sample with a total copper concentration $c_{\mathrm{Cu}}=34$ at.\% as in as-deposited condition and after heat treatment at temperatures $600 \leq T_{a} \leq 900 \mathrm{~K}$.

4. Heat treatment of film samples with total concentration copper $19 \leq c_{\mathrm{Cu}} \leq 51$ at.\% in the temperature range $600 \leq T_{a} \leq 900 \mathrm{~K}$ had almost no effect on the value of GMRs. It indicates the thermal stability of the magnetoresistive properties of thin-film alloys based on $\mathrm{Py}$ and $\mathrm{Cu}$.

\section{ACKNOWLEDGMENT}

This work was partially funded by the State Program of the Ministry of Education and Science of Ukraine No $0120 U 102005$ (2020-2022 years).

Yu.M. Shabelnyk, V.O. Kravchenko, Eur. Phys. J. Plus 132, 58 (2017).

6. A.E. Berkowitz, J.R. Mitchell, M.J. Carey, A.P. Young, S. Zhang, F.E. Spada, F.T. Parjer, A. Hutten, G. Thomas, Phys. Rev. Lett. 68, 3745 (1992).

7. I.P. Buryk, D.V. Velykodnyi, L.V. Odnodvorets, I.E. Protsenko, E.P. Tkach, Tech. Phys. 56, 2, 232 (2011).

8. L.V. Odnodvorets, I.P. Protsenko, Yu.M. Shabelnyk, M.O. Shumakova, O.P. Tkach, J. Nano- Electron. Phys. 8, 3, 03034 (2016).

9. I.Yu. Protsenko, P.K. Mehta, L.V. Odnodvorets, Yu.M. Shabelnyk, N.I. Shumakova, J. Nano- Electron. 
Phys. 6 No 1, 01031 (2014).

10. M.-D. Cubells-Beltrán, C. Reig, J. Madrenas, A. De Marcellis, J. Santos, S. Cardoso, P.P. Freitas, Sensors 16, 939 (2016).

11. K.V. Tyshchenko, L.V. Odnodvorets, I.Yu. Protsenko, Metallofiz. Nov. Tekhnol. 33 No 10, 1351 (2011).

12. O.V. Synashenko, O.P. Tkach, I.P. Buryk, L.V. Odnodvorets, S.I. Protsenko, N.I. Shumakova, Probl. Atom. Sci. Tech. 6, 169 (2009).

13. I.O. Shpetnyi, S.I. Vorobiov, D.M. Kondrakhova, M.S. Shevchenko, L.V. Duplik, L.V. Panina, V.I Grebinaha, Yu.I. Gorobets, L. Satrapinskyy, T. Luciński, Vacuum 176, 109329 (2020).

14. Ia.M. Lytvynenko, I.M. Pazukha, V.V. Bibyk, Vacuum 116, 31 (2015)

15. O.B. Lasyuchenko, L.V. Odnodvorets, I.Yu. Protsenko, Cryst. Res. Technol. 35 No 3, 329 (2000).

16. O.V. Pylypenko, I.M. Pazukha, A.S. Ovrutskyi, L.V. Odnodvorets, J. Nano- Electron. Phys. 8 No 3, 03022 (2016).
17. S. Kenane, J. Voiron, N. Benbrahim, E. Chainet, F. Robaut, J Magn. Magn. Mater. 297, 99 (2006).

18. Yu.O. Shkurdoda, A.M. Chornous, V.B. Loboda, Yu.M. Shabelnyk, V.O. Kravchenko, L.V. Dekhtyaruk, J. Nano-Electron. Phys. 8 No 2, 02056 (2016).

19. M. Hecker, D. Tietjen, H. Wendrock, C.M. Schneider, N. Cramer, L. Malkinski, R.E. Camley, Z. Celinski, J. Magn. Magn. Mater. 247, 62 (2002)

20. S. Heitmann, A. Hutten, T. Hempel, W. Schepper, G. Reiss, J. Magn. Magn. Mater. 226-230, 1752 (2002).

21. Tawab Dastagir, Wei Xu, Saurabh Sinha, Hao Wu, Yu Cao, Hongbin Yu, Appl. Phys. Lett. 97, 162506 (2010).

22. D. Peng, J. Wang, L. Wang, X. Liu, Z. Wang, Y. Chen, Sci. China-Phys. Mech. Astron. 56, 15 (2013).

23. I.O. Shpetnyi, D.M. Kondrakhova, S.I. Vorobiov, B. Scheibe, V.I. Grebinaha, D.O. Derecha, Yu.I. Gorobets, I.Yu. Protsenko, J. Magn. Magn. Mater. 474, 624 (2019).

24. T.B. Massalsky, J.L. Murray, L.H. Bennett, H. Baker, Binary Alloy Phase Diagrams, Metals Park (Ohio: American Society for Metals: 1986).

\title{
Структурно-фазовий стан та магнітотранспортні властивості тонкоплівкових сплавів на основі пермалою та міді
}

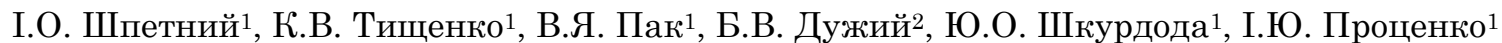

${ }^{1}$ Сулський державний університет, вул. Рилського-Корсакова, 2, 40007 Сули, Україна

2 Харківський національний аерокослічний університет "Харківський авіаційний інститут", вул. Чкалова, 17, 61070 Харків, Україна

\begin{abstract}
У роботі представлені результати досліджень впливу складу на структурно-фазовий стан та магніторезистивні властивості свіжосконденсованих та термооброблених при температурах $T_{6} \leq 900 К$ зразків плівкових сплавів на основі Ру та $\mathrm{Cu}$. Зразки тонкоплівкових сплавів товщиною $d=25$ нм в інтервалі складів $19 \leq c_{\mathrm{Cu}} \leq 69$ (де $c_{\mathrm{Cu}}$ - загальна концентрація $\mathrm{Cu}$, ат.\%) були отримані методом одночасного випаровування у вакуумі з двох незалежних випарників. Методом просвічуючої електронної мікроскопії було досліджено структурно-фазовий стан зразків плівкових сплавів при $c_{\mathrm{Cu}}=19$ ат.\%, 34 ат.\% та 61 ат.\%. Структура тонких плівок як в свіжесконденсованому так і у відпаленому при $T_{6} \leq 900 \mathrm{~K}$ стані складаються з квазігранул пермалою, вбудованих у немагнітну матрицю Си. Фазовий стан зразків при $c_{\mathrm{Cu}}=19$ ат.\% та $c_{\mathrm{Cu}}=34$ ат.\% у свіжосконденсованому стані та після термообробки при $T_{\mathrm{B}}=600 \mathrm{~K}$ відповідав ГЦК- $\mathrm{Ni}_{x} \mathrm{Fe}(x \approx 3)+$ ГЦК- $\mathrm{Cu}$. Після термообробки при температурах $700 \leq T_{6} \leq 900 \mathrm{~K}$ фазовий стан зразків при $c_{\mathrm{Cu}}=19$ ат.\% та $c_{\mathrm{Cu}}=34$ ат.\% відповідав $\mathrm{Ni}_{3} \mathrm{Fe}+$ ГЦК-Cu. Для зразка плівкового сплаву при $c_{\mathrm{Cu}}=61$ ат.\% у свіжесконденсованому стані та після термообробки

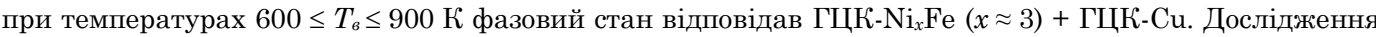
магніторезистивних властивостей плівкових зразків показали, що плівкові зразки у всьому інтервалі складів $19 \leq c_{\mathrm{Cu}} \leq 69$ ат.\% характеризувалися ізотропним магнітоопором. Максимальне значення гігантського магнітоопору спостерігалося для зразка з $c_{\mathrm{Cu}}=34$ ат.\% як у свіжосконденсованому стані так $\mathrm{i}$ після термообробки при температурах $600 \leq T_{6} \leq 900 \mathrm{~K}$. Термообробка зразків в інтервалі температур $600 \leq T_{\varepsilon} \leq 900 \kappa$ майже не вплинула на величину ГМО плівок при $19 \leq c_{\mathrm{Cu}} \leq 51$ ат.\%.
\end{abstract}

Ключові слова: Ефект ГМО, Спін-залежне розсіювання, Пермалой, Суперпарамагнетизм. 